\title{
Access to Education for the Children of Sex Workers in Bangladesh: Opportunities and Challenges
}

\author{
M. Mahruf C. Shohel" \\ The Open University
}

\begin{abstract}
The children of sex workers in Bangladesh are denied even the most basic human rights. This article is based on recent research focused on the children of sex workers in the context of their everyday lives. The study focused on access to education and how education could be a vehicle for them to break the vicious cycle of exploitation. This was a mixed method interpretative study which employed qualitative and quantitative approaches, but in this paper only qualitative data which was generated through in-depth interviews and focus group discussions is used. Data was collected from sex workers, their children, teachers and NGO workers who participated in the study. Information has been collected for analysing the expectation of the children of sex workers and hope for the future, and the opportunities available to them during their schooling. Thematic analysis technique was used to understand the challenges and barriers faced by the children of sex workers in fulfilling their educational aspirations. The lives of the children of sex workers are marginalised by the mainstream society. Though it is very difficult to break the vicious cycle of exploitation, this research finds that education may be a stepping stone for them to create a better future. However, it is argued that the children of sex workers need income generating vocational and technical education to enable them to earn and support their family. Policy recommendations have been made in order to achieve Education For All targets and Millennium Development Goals, and to provide a second chance for these vulnerable young people to have a better life.
\end{abstract}

Keywords: access to education, the children of sex workers, education for all, millennium development goals, Bangladesh

\section{Introduction}

The children of sex workers are excluded from mainstream society and denied even their most basic human rights such as housing, health and education due to a number of complex factors such as their position in a 'legal vacuum', a lack of political commitment and most significantly the conservative society in

* Corresponding Author: M. Mahruf C. Shohel, Research Fellow, Department of Education, Faculty of Education and Language Studies, The Open University, Stuart Hall Building L3, Walton Hall, Milton Keynes MK7 6AA, United Kingdom, E-mail: mahruf.shohel (a)open.ac.uk
Bangladesh. They are the victims of the power structures in their local community as well as the greater society that leaves them exposed to inhumane life conditions such as the obligation of drug abuse, lack of access to pure drinking water and sanitation, no property rights and legal protection, extortion, people trafficking and everyday violence.

In this context the children of the sex workers in Bangladesh are not in a safe environment, and there is a lack of focus on their personal development with an increasing risk of them becoming victims of the dangerous racket of the sex trade and exploitation (UNICEF, 
Shohel

2005). Children living in brothels have disproportionately limited access to education in Bangladesh (UNICEF, 2009). The children of sex workers are still deprived of their right to education, and few of them are enrolled in government schools. Most of them dream of rescuing their mothers from prostitution (Shohel et al., 2012). However, in reality the children are often cruelly ragged about their mother's profession (Adhikari, 2012). Their identity makes it stressful for them to continue going to school (Shohel et al., 2012; Jena, 2010).

This empirical study focuses on access to education for the children of sex workers in Bangladesh. Furthermore it explores how education could be a vehicle for them to break the vicious cycle of exploitation. It also shows how local NGOs are supporting and providing education for them. Thus the purpose of the study is to present current states of the children of sex workers in Bangladesh.

\section{Education for All (EFA) and the Children of Sex Workers: The Bangladeshi Context}

Education empowers, provides choices, and a voice to disadvantaged children and young people. It also promotes well-being by teaching them about good health practices, active citizenship through developing skills for life and a sustainable future. In these ways it helps socioeconomically disadvantaged children to break the poverty cycle and to have a better future. It provides the stepping-stone to self-development for those who are disadvantaged by creating choices, and builds self-confidence and selfreliance for individuals (Shohel, 2012).

The international calls, starting from the Jomtien Conference to Daker Forum and then the United Nations Millennium Development Goals (MDGs), clearly emphasized on the need for universal access to meaningful education (WCEFA, 1990; Dakar Framework for Action, 2000). Bangladesh became an enthusiastic signatory to the World Conference Education for All (WCEFA) framework at Jomtien, Thailand where the world community has strongly backed up the goal of 'Education for All (EFA)' at global gatherings. The government of Bangladesh has made commitment in the World Education Forum held at Dakar, Senegal in April 2000, towards the achievement of EFA.

According to the Child Rights Convention (CRC), every child has the right to be educated and children's rights have legal, political, social, cultural, economic, demographic and environmental dimensions. Among all vulnerable groups, children living in brothel areas are at high risk of deprivation, abuse, HIV transmission and trafficking. There is very little scope of them getting access to education. Children of brothel-based sex workers are stigmatised from birth. Their acceptance into the mainstream society is virtually impossible and consequently they often start working in the brothel themselves (Adhikari, 2008, 2007).

Providing education to the children of sex workers is not an easy task in the Bangladeshi context. There are barriers from society, from the local community as well as from the brothel. This study focuses on the Daulatdia Brothel, where many NGOs, such as Karmajibi Kallyan Sangstha (KKS), Mukti Mohila Samity (MMS), BRAC, as well as Save the Children, and ActionAid Bangladesh, with its partner organisations are running education programmes for the children of sex workers.

In 1993 KKS established a preschool to provide informal education for children who lived with their mothers in the Daulatdia brothel. Later an informal pilot project providing schooling for 25 girls started inside the brothel. Simultaneously four satellite education centres were established with 100 children taken outside the brothel area. This was the first attempt to provide education to the children of sex workers in Bangladesh. There were problems when the children of sex workers enrolled in regular schools. It was difficult for teachers and children to accept them as equals to their classmates. Children from mainstream society were not willing to sit next to the children of sex workers and as a result the children eventually dropped out (Shohel et al., 2012).

In 1995 a private school was established by the KKS with the help of Save the Children 
(formerly Save the Children Australia) to provide education for the children of sex workers and the children from mainstream society under one roof. The ratio of inclusion was 2:3 (mainstream children: children of sex workers). The main barrier which stood in the way of running this school was the mainstream community. At that time, the community showed an unwillingness to let their children study with the children of sex workers. Afterwards, however, Save the Children organized several meetings with the community to convince them about inclusive education for the children of sex workers with the mainstream children so that the children of sex workers could be socially included. Save the Children succeeded to take responsibility for 5 girls from the brothel and arranged their accommodation, food and education free of cost. At first the school was not getting any children other than the children of sex workers. However, gradually children from hardcore poor families also started to get enrolled in the school. Finally this school was included in the Government funding in 2004. Now the school is running with success and has earned considerable recognition. Children from all socio-economic backgrounds come to study here along with the children of sex workers. Even parents of different backgrounds, including sex workers, attend parent-teacher meetings and other school programmes.

Shapla Mohila Shangstha (SMS), an implementation partner of ActionAid Bangladesh $(\mathrm{AAB})$ in Faridpur, operates a child development centre under the 'Promoting Human Rights of Destitute Women and Children Project'. The centre was established in 2004 to bring the children of sex workers into mainstream society and enhance their life skills. At the centre, the children are provided with facilities including day and night shelter, a healthy diet, mainstream education as well as extracurricular and recreational activities. Currently the centre's rented accommodation can accommodate only 25 children but a new permanent building, which is under construction, will be able to house another 75 children.
As NGOs have been taking initiatives to change the society-wide perceptions of the children of sex workers, access to education along with the mainstream society has become easier for them. Especially after the establishment of the KKS primary school and the safe hostels of Save the Children and PIACT Bangladesh, the situation has started to improve, and access of the children of sex workers has become easier to both in primary and secondary schools. Because of the NGO support, their school performance and quality of education is now much more satisfactory. For example, a sex workers' daughter got a GPA (Grade Point Average) of 4.88 (out of 5) in the Secondary School Certificate (SSC) exam and another received a scholarship in Grade V. Now many of them are also able to gain admission to the Higher Secondary Certificate (HSC) course or to some other stage of further education.

In Bangladesh, normally the 'sex trade' is not legal except in fifteen government approved brothels across the country (Alauddin, 2005). However, a recent ruling by the Bangladeshi High Court states that prostitution is not illegal as a livelihood (BBC, 2000). That means prostitutes have the legal authority to practice their trade in Bangladesh and this is highly unusual. It makes Bangladesh one of the few Muslim majority countries that does not ban prostitution (Hosain \& Chatterjee, 2005). Women and children are found involved in the sex trade in these brothels from all social strata, caste and religion. They are the most deprived, tormented, ill-treated and misused people as is the case in many other developing countries. Daulodia brothel is the most recent one within the country and, after the closing down of the Tanbazar brothel in 1999, it became the largest one in Bangladesh (Terre des hommes Italia, 2005). Although sex work has always existed in Bangladesh and taken many changing forms, sex workers and their children remained ignored and avoided by academic researchers. However, over recent years a handful of research studies have been conducted (Karim, 2004).

A study on the living conditions and socioeconomic status of brothel-based and floating 
(street walkers) sex workers in Bangladesh made a general assessment of their living conditions and found that the reasons for entering the brothels are poverty, deception, abuse, coercion and rape. Most of the sex workers come from an ultra poor background and are usually illiterate or have a low level of education and no marketable skills. They generally face disruption of the family units and their lives, along with their children are full of suffering (Terre des homes Italia, 2005).

Another recent study (UNICEF, 2011) was carried out to review and assess the "National Plan of Action 2002" to combat child sexual abuse, commercial sexual exploitation and trafficking. The study found perpetrators of child sexual abuse to be men in the vast majority of cases. Different research findings show that parents' drug use or sex work is often illegal and hidden in the society they live in, so identifying their children can be difficult and may increase the children's vulnerability and marginalisation. Researchers and service providers, therefore, need to proceed with caution when attempting to reach these populations, but documentation and evaluation of current programmes should be prioritised (Beard et al., 2010).

Though many NGOs are running education programmes for no research has been carried out to explore the impact of education on the lives of the children of sex workers. It is very important to understand challenges and barriers to access to education for the children of sex workers and how education impacts on their lives. There are many educational programmes running in and around the Daulatdia brothel performing the function of training sex workers for a 'better life' and to promote access of the children of sex workers to the formal education system by sensitising the wider society to their legitimate needs. This study aims at exploring the impact of education on the children of sex workers.

This understanding is essential to facilitate empowerment of the children of sex workers and to bring them out from the curse of exploitation and social isolation. Literature related to education of the children of sex workers is hardly found although adequate studies are available on their health issues, socio-economic status, abuse and violence.

\section{Method}

This mix method interpretative study focused on children of sex workers in the age range are 5 to 16 years. Quantitative and qualitative approaches were employed to have a better understanding and triangulation of the generated data. However, the major part of the study was based on qualitative methods and findings, whereas the quantitative part was used to support, validate and judge the qualitative findings. The information was collected through survey questionnaires of socio economic information, an interview schedule for sex workers and their children, and focus group discussions (FGD) with teachers, NGO resource personnel and education activists. Fieldwork was carried out during July-August 2012. Six research associates were trained and involved in the data collection.

A purposive sampling method was employed on the basis of availability by using the snowball sampling technique. At first, thirty sex workers' families had been selected purposively from the brothel in order to collect socio-economic information. The selection criterion for the families was that they should have at least one school going children in the family. The number of the children of sex workers that participated in this study was thirty. Twenty of the sample children were being educated at primary level and the rest were from secondary level. Efforts were made to ensure gender balance among the respondents. They were interviewed separately in their school or the 'safe home' where they stay. Thirty sex workers were selected for interview. Interviews were conducted individually with each of the sex workers in different places. Eight primary and eight secondary teachers of the children of sex workers as well as eight NGO workers were selected purposively for three Focus Group Discussions (FGDs). Hence, the total number of research participants was 84 .

The sex workers' families sampled are 
situated both inside and outside the brothel. The sex workers hold various positions such as bharatia (sex worker who works independently by renting a room in the brothel and controls her own earnings) and bariwali ${ }^{1}$ (the female owner of a brothel home) (Terre des homes Italia, 2005). Teachers were selected from such schools which had been primarily established for the children of the brothel and the NGO workers selected were among those who work inside and outside of the brothel for the education and welfare of the children of the sex workers.

During systematic literature review, an analytic document was prepared on stakeholder engagement strategy (Thomas \& Mohan, 2007), and then intensive sharing and feedback sessions were conducted on draft research tools with the research associates to develop the final ones. Afterwards through an effective piloting of the research tools, they were finalized with relevant changes based on the feedback from the pilot phase.

\section{Research Site and the Feature of Daulatdia Brothel}

The geographical location of the study is Daulatdia in Rajbari Sadar Upazila, situated on the bank of the river Padma. It is about $130 \mathrm{~km}$ away from Dhaka, the capital city of Bangladesh. Among the fifteen recognised brothels, Daulatdia brothel is the largest in Bangladesh. It is located close to a very busy ferry port in Rajbari district in the western part of Bangladesh and has been operating for more than 25 years. It encourages a culture of corruption, violence, gambling, alcohol use, drug use and dealing, the open screening of explicit films and sex workers seeking customers. Approximately 3,000 people live inside the brothel including 1,000 children, 240 of whom are working as sex workers (some from the age of 8 upwards). These children are regularly exposed to sexual and physical violence. They are known to consume drugs and alcohol from as young as 10 years old (Save the Children Australia, 2012).

1 'Madam' is a title given to such women in the west- often former prostitutes who have now passed their prime.
The brothel provides financial benefits to a whole range of individuals, which means that there are many people in positions of power who have a vested interest in the brothel continuing to function in its current form, including the promotion of child prostitution. Mothers do not know how to protect their children from sexual and other abuse, exploitation and violence. Children are vulnerable to physical violence and sexual, physical and emotional abuse from a range of perpetrators including their peers and their mother's customers. Although most of the focus is on the protection of girls, boys are often victims too.

Sometimes poverty-stricken or otherwise vulnerable women and children, especially orphans, become victims of trafficking. Dalals (agents who are engaged in collecting and selling women or children to the brothels) offer them jobs and lure them in different ways to come to the brothel. The entrants to the Daulotdia brothel are from these disadvantaged groups. Some NGOs such as PIACT Bangladesh and MMS are working extensively to prevent under-aged children from becoming victims of trafficking.

\section{Ethical Considerations}

It is not always easy to identify and respond to ethical dilemmas (Holland \& Kilpatrick, 1991), an obvious question in social research is: how are the ethical issues and dilemmas negotiated in the real world, especially involving such a range of vulnerable people? The study adopted a code of practice which entailed obtaining informed consent from head teachers, teachers, sex workers and their children, and the related authorities of the NGOs involved in the study site. All information was collected under strict confidentiality and anonymity, showing attitudes of tolerance, empathy and respect towards the socio-cultural norms and taboos of sex workers, taking gender balance into consideration in case of selecting research participants, conducting interviews at times and places convenient for the respondents, and spending sufficient time in the field to keep close contact with the participants to build rapport. Due to suppression and taboo, 
the sex industry is largely underground; so the collected data has been kept confidential in order to protect the community from any kind of harm and distress. Throughout the study, ethical issues were addressed consciously. This study was carried out by following the guidelines of the British Educational Research Association (BERA, 2011) and the British Psychological Society (BPS, 1995).

\section{Data Analysis}

The grounded theory approach was employed to carryout data analysis (Strauss \& Corbin, 1990; Glaser \& Strauss, 1967). To analyze the data, the process suggested by Marshal \& Rossman (1999), was adopted; where they recommend following the sequence of organising the data, developing the themes and then interpreting the data. Thematic analysis was followed and the results grouped together to answer the research questions: Do the children of sex workers have access to education?; What are the opportunities and challenges for them to getting access to and continue education? Thirty case studies of the children of sex workers were drawn from the derived data which illustrate the overall findings of the research. Peer debriefing (Spall, 1998) was done before finalising the report.

\section{Findings}

\section{Opportunities for getting access to and to continue education}

The children of sex workers who participated in the research did not face any problem gaining admission in the schools. They start their preprimary education from MMS and a special school called the KKS School. They get all necessary materials like books, stationery and uniforms from the schools. The schools and safehouse residence authority run by NGOs provide the necessary educational materials which helped them to carry on their study. The school environment is better than the environment inside the brothel which encourages higher attendance. One of the research participants said:

There is an opportunity to admit to the KKS School. There is no barrier to admit to the KKS School for a brothel child. All types of children are admitted here. A brothel child play and mix with a community child. [Interview with sex worker]

MMS provides pre-primary education through 10 pre-primary centres and 3 informal education groups. According to MMS staff, their organisation succeeded in including almost $100 \%$ brothel children in their Early Childhood Care and Development (ECD) Programme. KKS schools provide education from primary to higher secondary level for the children of sex workers. MMS and KKS are mostly financed by international organisations. Besides this, PIACT Bangladesh provides accommodation for some children of sex workers.

I have everything here. I have separate chair, table for study. For sleeping there is a bed for me. In the safe home there live $3 / 5$ children in each room. Everybody has separate bed. [Interview with child]

I have everything like, chair table, electricity and study space. We have a TV in PIACT Bangladesh safe home. Four teachers always help us for preparing our study. [Interview with child]

The children of sex workers perform well in co-curricular activities such as reciting poems, singing, dancing, stand up comedy, quiz competitions, indoor and outdoor games in the cultural programmes and annual sports competitions organized by the schools. Some other children practice drawing, singing and dancing in the MMS ECD Centre. The children of sex workers also perform well in exams. Some of them achieving more than $80 \%$ marks in the previous exams and they are satisfied with 
their results. Regarding progress of her child a respondent said:

I am pleased. His result in school is good. He does not like to mix with the community people of this brothel. He does not involve himself in any bad activities like taking drugs. He has come out from this environment and continuing his studies. So, I am pleased with the result whatever he performs. [Interview with sex worker]

On the contrary, another respondent said:

No, I am not pleased. He should do better. I want to admit him to diploma engineering. He will have to do better to attain admission requirements of this course. [Interview with sex worker]

There was an exception in a response of a respondent. She said:

He is getting very good results. I cannot go to school to discuss with the teachers about his class performance as my son forbade me to go there. He feels humiliated by who I am and is ashamed when I go to school. So I cannot talk to the teachers about his progress. But he shows me his progress report. His class position is 8 now which was 14/15 in class $I X$. So he is improving. [Interview with sex worker]

Most of the children reported that school is their favourite place since they can learn many things and can play with their friends. Some children live in safe homes of KKS and PIACT Bangladesh. They do not need family support for their studies and are provided with conducive conditions for studies at the safe homes.

NGOs and individuals have made efforts to create opportunities for the children of sex workers to continue their study. The girls of sex workers can study up to Grade XII in Abdul Zobbar Girls High School and College. In Daulotdia Model High School (DMHS) both boys and girls can study from Grade VI to Grade
X. After passing the Higher Secondary Certificate (HSC) exams they go to colleges such as Goalondo College and Rajbari Government College. Some of them also go to polytechnic institutes in Dhaka, Chittagong, Kushtia and other areas of Bangladesh.

Tuition fees and other expenses are covered for the children who go to primary school run by the NGOs. But children who go on to secondary school have to pay their tuition fees and other fees as well as purchasing some learning materials. As a result, after completing primary education many children of sex workers do not enrol at a secondary school. Therefore, their economic condition starts creating a barrier to continuing education.

Most sex workers struggle to provide the essential things for their children. They may even have to take loans at a high interest rate to meet their children's educational needs. Economic problems create a barrier here since life inside the brothel is already very costly. This is evident from the following statement:

I have to provide her guide books, paper, pen, school fee, school dress bag and so forth. When my earnings are sufficient, I can provide all these things. But when it is poor, I have to take loan at a high interest rate (100 taka interest at 1000 taka/month) from a local jewellery businessman if she needs anything urgently. [Interview with sex worker]

According to a teacher:

Because of financial difficulties, sex workers sometimes try to stop their daughters' education in order to get them engaged in sex work. Early marriage is one of the big challenges in the brothel locality as there is continuous pressure on the mothers to marry off their daughters at an early age. Marriage is used as evidence to 'prove' that a girl is eighteen so that she may be involved in sex trade. [FGD-I]

As most children of sex workers are first 
generation learners, there is no one in their home who can help them with their study. Only 14 out of 30 children interviewed get help with their study at their residence from their elder sister or brother. The rest of them do not have that opportunity. They do their homework themselves without assistance from anyone.

No, there is nobody at my home who can help with my study. But MMS arranges teaching session for us in afternoon. I go there from 04:00 pm to 6:00 pm. [Interview with child]

PIACT teachers help me to complete my homework or study. There are four teachers (2 male and 2 female). I called aunty to the female teachers. Fourteen children stay in PIACT home. My cousin helps me also. [Interview with child]

Those who live in a brothel said that the brothel does not act as a supportive environment for studies.

I don't have chair, table but I have books. I usually read sitting on my bed. We have electric supply here. But the main challenge is that the environment surrounding our house is not congenial for reading. There is huge noise as our house is beside the railway station. Sometimes, my neighbours listen to songs with high volume. So it is difficult to concentrate on my studies. [Interview with child]

I have study space, chair, table, electricity etc. in my home. But there is drug (heroin, cocaine) shop and wine shop beside my house. It makes the surrounding environment noisy and terrible. It sometimes hampers my study. Anyway I am trying to continue my study in this environment. My mother is giving the main support. [Interview with child]

The safe residences authority appointed some care workers who help the children with their study in their residence. According to an NGO worker:

Some of the sex workers whose children live in the safe home of KKS have to pay according to their ability to do so. The children are able to stay there and tutors are made available to them who teach them privately. Some of them occasionally get monetary help when their families cannot pay the tuition fees due to financial difficulties but this help is generally found to be insufficient. [FGD-III]

\section{Challenges in getting access to and continuing education}

Though most of the teachers are good, a few teachers have been reported to be prejudiced and biased. According to some children and their mothers, some teachers giving less attention to the children of sex workers. One girl reported that:

Some teachers do not give much time if we struggle with a lesson. They chat and spend more time with the children from the village (who are not the children of sex workers). But some teachers treat all the children equally. [Interview with child]

Sometimes other children behave badly withthem due to their mothers' occupation. As one of the respondents said:

I want to continue her education but the environment is not good here. Children use bad language more. My daughter mixes up with different types of girls. She is learning bad things from others. [Interview with sex worker]

A respondent reported:

Community children behave badly with my child. That is the main difficulty to continue my child's education. [Interview with sex worker] 
Some of the children said that they do not feel comfortable in schools, for which their experiences were not good all the time. Some of the children from the local community have a tendency towards behaving badly with them owing to them being the children of sex workers. The boys play pranks on the girls and tease them. According to a sex worker:

My child told me that he does not like to go to school because community children behave badly with him. They called him names like son of a bitch, son of a prostitute. Even some of them told you have no father. You are a bad mother's child. For that reason he said that his school experience is not good. [Interview with sex worker]

Seven or eight months ago, one classmate told my child that, you are a daughter of bad woman. Your mother is not good. She does bad business. She is a prostitute. Then her grandmother goes to the school and complains about the boy. [Interview with sex worker]

A boy shattered in tears and said:

Yes, when I go to school children talk with me roughly and slang language. They told that my mother is not good. She does bad profession. Even they told that I am a son of prostitute. I have no identity of father. So that I feel bad and I cry. [Interview with child]

The children of sex workers are treated differently because of their mothers' professional identity. Sometimes the other children use abusive language to the children of sex workers causing pain and insecurity. Some sex workers hide their identity to save their children from this social phenomenon.

I don't come in for the guardian day though I get an invitation. I become shy as I have studied in this school but now I come to my teacher as a prostitute. It is not pleasant for me rather I am ashamed. There is another reason behind not going to the school and that is my son doesn't like how I make my living. Nowadays, when we go to school, the teachers ask about the activities of sex workers and embarrass us. So we do not go there too much. [Interview with sex worker]

I want to go school regularly because I like my school. But some children behave very roughly with me. Even they bite me. They told me my mother is not good. They live in the community. I complained to my teachers but they do not punish them. Teachers told that you do not go to them. You mix with other children. Even teachers scold me. [Interview with child]

Nobody knows that I am a sex worker as we live outside the brothel and spend little time there. Only the teachers and NGO staff know that I am a sex worker. So it does not create a major problem for my child. [Interview with sex worker]

The children of sex workers are severely deprived of their mothers' affection, love and care. They do not like their mother's profession and they want to bring them out of the brothel. Absence of paternal identity and care has also been noticed as a reason for insecurity among the children. There are many sex workers who cannot give enough attention to their children's education because of poverty and their living conditions.

My child stays in the PIACT safe home. So, I have no chance to teach my son. [Interview with sex worker]

I get very few times to spend with her as I live in PIACT Bangladesh. When I go home, I don't get her there all the times. She remains busy with her business in the brothel. [Interview with child] 
I don't go to the safe home regularly. Mr. $X$ ordered us not to go to the safe home regularly or to meet with our child regularly as we live in the brothel. So I cannot say whether she goes to school regularly or not. [Interview with sex worker]

Security is a vital challenge for the girls as they are the most vulnerable in being abducted and trafficked while on their way to school. Sometimes they face sexual harassment and abusive comments from the local boys. At the moment, travel from the school to their living places is not safe. It was observed that mothers are apprehensive about the social situation regarding the safety of their children. Often their daughters are harassed and sometimes the situation may become even worse; according to two interviewees a school girl was allegedly raped a few days before the field visit, and the mothers, as a result, demanded safe conveyance of their child from home to school.

Last month violence occurred in this village. Some bad boys raped a small school girl. They also killed the girl. We always feel tense about this. My daughter goes to school alone. We have no one to carry her to the school. So we need a way to carry the child from home to school. [Interview with sex worker]

According to the teachers, the boys do not continue their study because of lack of proper guidance from their family. When they get involved in any income generating activity they are discouraged from going to school. Some of them collect wine, drugs and cigarettes for their mothers' clients and get paid for the service. Slowly they get involved in this and, eventually, stop going to school.

The children of sex workers sometimes feel inferior due to lack of paternal care and identity which affects them psychologically. Usually children in schools are identified with their fathers' identity but most children born in brothel do not know their father. As a result they face problems in getting government jobs ${ }^{2}$.

I don't know about my father. I can say about mother only. She is working hard for us, gives much time for me whenever she is free while doing business. She meets with me regularly to know about the status of my studies. So I like her. [Interview with child]

I have no friends outside the school because I stay in PIACT Bangladesh home. I have friends on my PIACT home. All of their mother stay in brothel. [Interview with child]

The children of sex workers have the same potential as other children but most of them suffer from poor attention and guidance. Teachers are often very conscious about their studies but they do not perform well because of a lack of proper study conditions at home and due to the lack of guidance from their families. Some parents do not want their children to continue their education but the teachers try to motivate them to continue their study and persuade the guardians to keep them away from the sex trade.

\section{Role of education to protect the children of sex workers}

Education is most important for sex workers' children because it can help them to improve their lives as well to help their families. The sex trade has no long term future and one will have to quit after a certain age. Most sex workers have financial difficulties. Therefore through education, their children can arrange rehabilitation for their mother. They can also get involved in some income generating occupations after receiving education. Thus education is also helpful for their mainstreaming into society.

I know that a mother is taking wine, heroine, fencidile with her children together. But I don't want this. I sent the

2 Application forms of jobs in the government sector of Bangladesh usually require the father's name of the applicant. 
child to the school so that he can build up himself as a true human being. I did not want to involve him in the activities of the brothel. I want that he will be a businessman like his father (my Babu) after completing his education. For that reason I enrolled my child in school. [Interview with sex worker]

Getting enrolled in a school is reportedly the most significant event in some of the children's lives. Education has influenced personal and social life of the children of sex workers to a large extent and their social status has changed over time. Their children are treated with increased respect in society as they go to school.

Education has influenced on me the most. Now I can hope to become a good human being. If I didn't get admission to the school, I would become spoilt by this time. I might be involved in drug business or something like that. [Interview with child]

The environment of school is good and teachers and children behave well with me. So I think this admission of this school shaped my life most. [Interview with child]

The teachers' inspiration also helps the children aspire towards high goals and motivates them to attend schools. One of the NGO workers said that:

Living in the safe homes, as opposed to the brothel, is one of the most defining factors of their present lives. After receiving education, their outlook about life is gradually broadening. They want to be well established, economically solvent and self-reliant persons by being educated. They hope and wish to contribute to their families and help their mothers live with 'dignity' out of the isolated world of the brothel. [FGD-III]

Only a few sex workers are involved in their children's school activities as guardians. Most of them do not want to visit the school as they feel embarrassed to be in front of teachers and other guardians. Nevertheless, they do visit the school to be informed about their children's educational progress and to collect their children's report cards. They also participate in the parent-teacher meetings and annual sports days. Some of the sex workers who have high aspiration with their children's future also expressed dissatisfaction with their child's educational progress. But most of them were pleased with the very fact that their children are going to school to be educated.

\section{Impact of education on their lives}

The children used to play around aimlessly all day with each other before they started going to school. Now they are busy learning, playing sports, doing household works or recreational activities like watching TV programmes, chatting with friends and family members during their leisure times.

Before going to school I used to spend my free time with my mum, going to cinema or going here and there. Now I play cricket, computer games, watch cartoon on TV and gossip with my mother during my free time. [Interview with child]

I would spend my free time in past by playing whole day. Now during my free times I watch TV in my uncle's house, play with friends, and do some household works etc. [Interview with child]

The behaviour of children of sex workersimproved after admission to school. According to one NGO worker:

They started to respect people, stopped using bad language, and became motivated to study. None of the school going children used any drug (such as steroids) for their early growth, a practice that could otherwise affect them if they were to be rushed into the brothel life. [FGD-III] 
All the children have the desire to obtain higher education and they expect to be admitted into universities for higher degrees.

When she came to the village she could not speak nicely. Because of staying at the brothel she learned some bad language also but after going to school she started to speak nicely. She stopped using slang. Now she behaves very well. She does her home work regularly and also learns her lesson everyday. I am happy with her progress and the change in her behaviour. [Interview with sex worker]

Some respondents feel that some of the children were not behaving well with their parents and others before going to school. They did not want to help their mothers with their household chores. After starting to go to school the children of sex workersshowed some positive changes in their behaviour. They became conscious about their education, health and everyday use of language. After going to school the children now respect their elders. Though there are many positive changes among the children of sex workers according to the respondents, some parents did not observe any changes among their children.

Most of the sex workers feel that education has a positive impact on their children's lives and that their behavioural changes are satisfactory. After receiving education they have stopped using swear words in their daily conversations. There is evidence to believe that in some cases education helped the children to reject bad influences.

In past he got free time to mix with spoilt friends but he now remains busy with his study. [Interview with sex worker]

They are becoming accepted as part of the society after being educated which is a great improvement. Now the children of the 'mainstream society' and the children of sex workers study in the same school. The children of sex workers who are already in touch with the mainstream society think that their mothers' profession is not a good one. They want to bring their families out of the brothel and live a normal life.

The only disappointment of my life is that my mother lives inside (of the brothel). It would be better if my mother was not a prostitute even we could eat twice in a day instead of thrice. Nobody could call me a daughter of prostitute. [Interview with child]

The children of sex workers who complete their education generally get involved in different jobs like teaching, NGO work, driving, and paramedic work. Some also get engaged in small businesses like photo studios and computer workshops. Girls who never go to school or dropped out usually follow their mothers' footsteps. Boys who never go to school or dropped out are generally engaged in illegal drug trading, running errands to grocery shops and sometimes acting as pimps for the prostitutes.

One KKS school teacher is a sex worker child. We are proud of her. I want my child to complete her education and get a good job like her. [Interview with sex worker]

In this regard, one girl shared her experience:

There is no support for study from my family. I failed once when I was in Grade III. My mother wanted to take me to the brothel. She inspired from my aunt and wanted to make me a prostitute. I gave her dates and changed, but have not gone inside yet. [Interview with child]

They think that without education children may become involved in illegal activities, such as drug dealing. According to the children, the teachers of their schools are very cooperative and inspire them to be educated. Their teachers contribute to forming their aspirations. Their inspiration has helped them to change their lives. Their teachers have assured them that if they 
themselves are not interested to follow their mothers' profession, no one can force them to do so.

The children think that they will be able to be well established and self-reliant by receiving a good education. They will get a good job and be financially solvent. Moreover, they also feel that if they can change their economic conditions, it will be possible for their mothers to leave their profession and come out from the brothel. They will get the opportunity to live with the general people with 'dignity' and will not be socially isolated. They feel that all the family members will be able to live a happy life together. One of the mothers said:

When my daughter is grown up, she will possess the ability to judge what is right and what is wrong. She will take decision about her life. When girls enter their family life they forget their mother. So I don't expect that she will help me in future. But I like to see her self-dependent. [Interview with sex worker]

Another mother expressed her anxiety:

After completing her school or college level I will give her in marriage because I am afraid about my child's future. The environment of this area is not good. I have no interest to see my child as a sex worker. I could not tolerate it. I want to see my child having a normal life. [Interview with sex worker]

There is reason to believe that education is bringing changes to the attitudes and behaviour of the children of sex workers. The head teacher of the primary school significantly noted that:

Education is also helpful in building awareness among the sex workers. It is also helpful in discouraging them from crime. They are more likely to be aware of the detrimental effects of drugs and other substances. Education can be used as a weapon by the children of sex workers to protect them from the environment they live in. [FGD-II]

\section{Aspirations for better future}

The children of sex workers are one of the neglected groups in Bangladeshi society. Nevertheless sex workers want to see their children as 'good citizens'. Most of them have high aspirations with their children's future and have sent their children to school since they are concerned about their future. They have admitted their children to school so that the children can have the opportunity to grow up as 'dignified' human beings. Most of them have high aspiration with their children's future.

I want to see my children as self dependent and independent citizens. I have enrolled them in school so that they can get a job after finishing their education. She wants to be a doctor in the future so she needs to study more. [Interview with sex worker]

Sex workers believe that their children should have access to a better education. If they receive a better education they will be able to get socially recognized jobs which will help them to lead their life with honour and status. One sex worker said:

I want a better future for my child and for that reason I enrol my child in school. If I did not enrol her in the school she would become a prostitute. Though I have spoiled my life I should not do the same to her. I wanted to make her future different than me. [Interview with sex worker]

Another sex worker echoed that,

I want my child to have a better future. I want to see her literate. People do not value someone without education. For that reason I admitted my child to the school. I did not get the opportunity to study in a school. I wanted to give my child this 
Shohel

opportunity as education has great importance in this age.

The children and their mothers have the expectation that they will be able to complete their higher education one day. As a result, they will be able to get a good job or run a good business. Some of the children of sex workers hope that they will be able to go abroad to get higher education.

I want to pass $B A$ and after that I will do a very big job. After completing grade VIII or IX, I will go to Italy and after completing study there I will come back again. My grandmother told me she will send me to Italy for study purpose. [Interview with child]

Most of the children feel they are more likely to attain their desired level of education since their parents are willing to show support for their education. They also believe that they will get support from their families in the future the same way they are getting it at present.

After the completion of education, most of the children expect that they will do a very good job. They want to be involved in different professions like doctor, engineer, lawyer, pilot and teacher, etc. Some other children want to be businessman. They want to become doctors because they will able to take care of the poor people and give them proper treatment free of cost.

I want to be a doctor because I want to take care of people, especially of the poor people. Many poor people die because of the lack of treatment. They do not get proper treatment for money. I will provide treatment for the poor people without money. [Interview with child]

On the other hand some other children want to be teachers as the teachers can teach children and can make a very good relationship with them.

I want to be a teacher. I like this profession because as a teacher I will be able to teach children and make good relationship with them. [Interview with child]

\section{Life skill based education to create a better future}

There are no arrangements for skill based education programmes for the brothel children in the existing schools. Children living in the safe homes get some life skill based training such as tailoring or cooking but their scope is very limited. Most NGO workers and teachers believe that general education is not enough for improving the well-being of the children of sex workers. One secondary school teacher said:

They need to have some technical and vocational education which would provide them with a real opportunity to enter the job market. [FGD-II]

None of the schools where the brothel children study arranges any kind of skill-based training or job oriented education. Nevertheless, some NGOs and safe residence authorities had arranged some skill based training programs for the brothel children so that they can earn a living from a socially recognized profession in the future. According to an NGO worker:

Sex workers did not allow their children to attend this kind of training before completing their education. [FGD-III]

As they have financial difficulties, the education for the children of sex workers should be at the level and of a quality which will to help them be solvent in the future. Therefore, technical and vocational education is needed to provide them with opportunities to enter the job market immediately after completing their education.

After the completion of their education, most of the children expect to get good jobs. They have aspirations to become doctors, engineers, lawyers, pilots, teachers, businesspersons and so on. One student said that: 
It is my hobby to work with machines and I would like to invent new things. [Interview with child]

But most of the children said that their mothers expect them to, first and foremost, be good human beings. Their mothers would like to see them established in life so that they can take the responsibility of the family.

Most respondents believe that education can create a better future for the children of sex workers. One NGO worker said:

Through education they are getting the opportunity to interact with people of the 'outside world'. Education helps them to improve their and their families' lives. [FGD-III]

Most sex workers want their children to achieve higher education. Like mothers anywhere, sex workers wish that their children will one day become doctors, businessmen, servicemen, journalists or engineers.

\section{Discussion}

The children of sex workers are socially isolated from the mainstream society in Bangladesh. Many interlinked factors such as cultural background, social surroundings and physical facilities shape their lives (Shohel \& Howes, 2008). Early experiences from school, physical surroundings, with relatives, the reception from others also play a significant role in their lives.

The children of sex workers do not tend to have many friends in their locality as they think that the local people are not welcoming and treat them badly. They are instructed by their mothers not to mix with the local people. The children who are living in the safe homes have good relationships with their roommates as they do not go outside of the homes very often. However, the children of sex workers are now found to be getting along well with other children in their schools and are becoming more accepted in the school environment. But nevertheless they have to encounter several difficulties to continue their education. One difficulty mentioned by some respondents was the lack of proper study conditions. Moreover, some children are losing their motivation to go to school as they are not treated well and with dignity because of their mothers' profession. Some mothers are also struggling to manage their child's educational expenses such as private tutor fees and expenses to buy study materials. Others do not want to go to school as they are afraid of the teachers scolding them.

Though sex workers have many problems in their everyday life, they generally want their children to continue education as long as possible. They struggle with finances but, nevertheless, want to support their children. They expect their children to achieve a higher degree which will help them to get a good job and live their lives with dignity and social status.

From the interviews it was evident that boys from the brothel who do not go to school usually become addicted to drugs or get involved in drug dealing. Some also start acting as pimps for sex workers. Girls, who never go to school or dropped out, are usually prone to following their mothers' footsteps in to the profession.

The children of sex workers who receive education are employed in or choose different jobs such as teaching, driving, paramedics or even day labourers. The primary school teachers mentioned that some of them start their own businesses, such as photography shops and computer workshops. High school teachers added that some even go for higher education in universities and polytechnic institutes. Those who are still studying, have aspirations to be involved in good professions. They feel that it is necessary to change their and their families' lives and that in order to do so they must leave the brothel.

Most of the children believe that financial insolvency is the main challenge in attaining their goals. The support they get from their families is insufficient. In addition to that the children living inside the brothel think that the environment of that place presents a great barrier 
for them to shine. There is continuous external pressure on daughters of a sex worker for early marriage. Some children say that they do not get proper attention from the teachers due to the large number of children. They face lots of other challenges in fulfilling their aspirations, including, their parents' protectiveness, sexual harassment and the constant fear of being trafficked.

Majority of the sex workers expect that their children would grow up with better education so that they do not need to follow their footsteps and will be able to engage in a different service or profession rather than 'sex trade'. Sometimes these mothers are afraid especially that their daughters might follow their footsteps. This apprehension may motivate them to marry their daughters off after they pass SSC or college. It has also been observed that parents have different expectations and dreams for their children to be a part of society, though many different factors influence their aspirations.

Education is working as an empowerment tool for the children of sex workers. The NGO staff reported that after receiving education they are already taking up professions like teaching. driving, working as NGO workers or paramedics, as well as setting up small businesses like photography studios, desktop publishing shops etc. Using their education they are trying to facilitate their mothers' exit from the brothel. Their education is acting as a bridge between them and the outside world. The view shared by many is that those who did not complete their education had higher chances of being involved in the sex trade. It was found that providing technical training beside general education to these children could be a better option for their livelihood. None of the sex workers wanted their children to follow their path or to be engaged in the sex trade. Some sex workers reported that they did not want to make the same 'mistake' again by letting their children come in to prostitution.

\section{Policy Implications}

\section{Policy implications for the state}

If Bangladesh wishes to see itself as a just society, the children of sex workers should be treated like all other children and citizens of the country. Their fundamental rights need to be similarly protected by law (The Daily Star, 1998). Strong steps should be taken to save the children of sex workers from any kind of abuse. There should be a law to give the children of sex workers the opportunity of applying and getting government jobs without the identity of their father being required as most of them do not know who he is. The national education system should emphasize specially the education of disadvantaged groups and the State should provide them with free education. Special programmes should be undertaken for motivating sex workers to provide education to their children. Access should be equally smooth for the children of sex workers in any kind of educational institutions. Safety of the children should be ensured, especially with regard to safe conveyance to and from school. Safe accommodation should be arranged for the children of sex workers where they will get conditions that are conducive for their studies. Financial assistance such as stipend or education loan should be provided to the children of sex workers to continue their studies.

\section{Policy implications for the donor agencies}

Donor agencies should focus more on the safety issues of the children of sex workers . They should take the initiative to accommodate more children of sex workers (AHRC, 2002). Moreover alternative income generating programs should be funded and initiated for the sex workers so that those who are engaged in sex trade unwillingly are provided with viable opportunities to leave and support their children. Therefore, it is crying need for the sex worker to get intensive training on early childhood care and education. Donor agencies could make a great difference and contribution by providing 
funding available for such training programmes.

\section{Policy implications for national and international organisations}

Some mechanisms need to be developed in the National Plan of Action to include mothers along with other relevant partners such as NGOs, teachers, religious leaders and community leaders in the efforts for prevention, protection or reintegration of the children. It was apparent from the case studies that mothers play the most fundamental role in this and a greater role for them in the process is certainly called for. Close monitoring and supervision should be ensured for maximum output. Accommodation of large numbers of the children of sex workers should be given more emphasis on any intervention. The children of sex workers should be given some skill-based training so that they can earn their living without engaging in the sex trade. The children of sex workersshould not be treated differently by the teachers or other children because of their mothers' profession. A mental health care system needs to be established to provide counselling services and psychological treatment to the children who suffer from humiliation or psychological torment. Local affluent communities should be encouraged to come forward and donate scholarship funds for helping this underprivileged group of children.

\section{Policy implications for the mass media}

The media should highlight some awareness building programs to promote inclusive education for the children of sex workers with the 'mainstream' children. Adult learning programs need to be organised for sex workers which will facilitate their children's education. Attitudinal change towards sex workers is necessary as their social class (as perceived by the common people) hinders their ability to be integrated into the mainstream community and participate in community affairs. The media can play a vital role in this regard and should highlight the contributions and success stories of donor agencies and of the state regarding their education.

\section{Conclusion}

The sex workers who mostly end up in this trade are from rural backgrounds and suffer extreme poverty. They are mostly illiterate or hardly have any experience of going to secondary school. The process of growing up as the children of sex workers is a complex one in terms of the peculiarity of the family, its construction and role relation along with the socio-economic and cultural aspects (Billah, 2012; Adhikari, 2012). The problem of space and professional identity pushes out the children of sex workers from their mothers at an early stage of their life. The usual consequence of this is that the children neither get protection nor do they get the attachment with their mother and this in turn creates insecurities. But the safety and the education they receive through the support of NGOs mostly fail to provide the stepping stone to break out of the vicious cycle of exploitation and abuse. They need skill based and income generating education to earn and help themselves and their families financially.

A lack of access to education is one of the primary limits on human development. One of the Millennium Development Goals is to provide universal primary education (MGD-2). Education is one of the basic human rights, and no one should be deprived from this right. The study can safely state that if the children profiled did not get an education, they would be more prone to crime and following their mothers' footsteps into prostitution. For improving the lives of sex workers children, education can play a vital role. After completing education, the children of sex workers can get involved in different income generating activities and bring their parents and family out of the brothel and provide for better conditions for the whole family. Education changes the attitude and behavioural patterns of the children of sex workers and that in turn creates the opportunity for them to be integrated into the 'mainstream society'. Education is a tool for them to protect 
themselves from the conditions they live in. Education builds awareness among the sex workers. It can build awareness about crime such as drugs and smuggling. Therefore, the State, donor agencies, national and international NGOs should work together to provide skill-based vocational and technical education for the children of sex workers to facilitate their entry into the mainstream community. Providing education and life skills training should be the main focus to support sex workers' children to improve their life.

Acknowledgements: This study was funded by the Center for Sustainable Development, the University of Liberal Arts, Bangladesh, Agencia Española de Cooperación Internacional para el Desarrollo (AECID), and ActionAid Bangladesh.

\section{References}

Adhikari, H. (2007). Growing up in adverse milieu: Education and occupations of sex workers' children. Indian Journal of Social Work, 68(2), 282-307.

Adhikari, H. (2008). When the sex market rejects. Journal of International Women's Studies, 12(1), 91-93.

Adhikari, H. (2012). Attachment of stigma in sex workers' milieu (family \& community): A hindrance of psychosocial development of their children. Atilim Sosyal Bilimler Dergisi, 1(2), 95-110.

AHRC (Asian Human Rights Commission) (2002). Bangladesh's child sex workers: No place to go. Asia Child Rights Weekly Newsletter, 2(3). 27 November, 2002. Retrieved on November 13, 2012 from http://acr.hrschool.org/mainfile.php/0103/20/.

Alauddin, M. (2005). Widespread of AIDS in Bangladesh is a must, if we fail to prevent of spreading HIV Virus. Retrieved on July 9, 2012 from http://www.popline.org/node/ 255977.

BBC (British Broadcasting Corporation) (2000). Prostitution ruled legal in Bangladesh. Retrieved on November 15, 2012 from http:// news.bbc.co.uk/1/hi/world/south asia/677283. stm

Beard, J., Biemba, J., Brooks, M. I., Costello, J., Ommerborn, M., Bresnahan, M., Flynn, D., \& Simon, J. L. (2010). Children of female sex workers and injection drug users: A review of vulnerability, resilience, and family-centered models of care. Journal of the International AIDS Society. 13(Suppl 2):S6.

BERA. (2011). Ethical guidelines for educational research. London: British Educational Research Association.

Billah, M. (2012). Socio-demographic configuration of the sex labour trade in Bangladesh: Income expenditure portfolio of the sex workers. OIDA International Journal of Sustainable Development, 4(9), 51-62.

British Psychological Society. (1995). Ethical principles for conducting research with human participants. The Psychologists, 6(1), 33-35.

Dakar Framework for Action. (2000). Education for all: Meeting our collective commitments. World Education Forum. Dakar, Senegal, 2628 April 2000.

Glaser, B. G., \& Strauss, A. L. (1967). The discovery of grounded theory: Strategies for qualitative research. Chicago: Aldine Publishing Company.

Holland, T. P., \& Kilpatrick, A. C. (1991). Ethical issues in social work: Toward a grounded theory of professional ethic. Social Work, 36(2), 138-144.

Hosain, G. M. M., \& Chatterjee, N. (2005). Beliefs, sexual behaviours and preventive practices with respect to HIV/AIDS among commercial sex workers in Daulatdia, Bangladesh. Public Health, 119, 371-381.

Jena, M. (2010, 17 February). INDIA: Education as empowerment tool for children of sex workers. Inter Press Service (News Agency). Retrieved on July 9, 2012 from http:/www.ipsnews.net/2010/02/indiaeducation-as-empowerment-tool-for-childrenof-sex-workers/

Karim, S. (2004) Exploring the household compositions of female sex-workers in Brothel: Daulatdia, A case study. BRAC University Journal, 1(2), 33-48. 
Marshall, C., \& Rossman, G. (1999). Designing qualitative research. Thousand Oaks, CA: Sage.

Project Report, Safe Home Program for girls, Rajbari, (2009). Retrieved July 15, 2012 from http://www.footprints.org.au/project/36/Safehome-program-for-girls-Rajbari-2009.aspx

Save the Children Australia. (2012). Bangladesh: Child protection. Retrieved on July 15, 2012 from

http://www.savethechildren.org.au/where-wework/south-west-asia/bangladesh/childprotection.

Shohel, M. M. C., \& Howes, A. J. (2008). Informality of teaching and learning in nonformal schools: Sociocultural process as meso-systems of student development, Education 3-13, 36(3), 293-309.

Shohel, M. M. C. (2012). 'Childhood poverty and education in Bangladesh: Policy implications for disadvantaged children'. Working Paper 2012-10, UNICEF Office of Research, Florence.

Shohel, M. M. C., Ashrafuzzaman, M., Nazmi, S. N., Das, A. R., Babu, R., Mubarak, F., \& AlMamun, M. A. (2012). Impact of education on sex workers and their children: Case Studies from Bangladesh. In D. M. Sabet, T. Rahman, and S. Ahmad (Eds.), Sex workers and their children in Bangladesh: Addressing risks and vulnerabilities (pp.158-180). Dhaka: Center for Sustainable Development, University of Liberal Arts, Bangladesh.

Spall, S. (1998). Peer debriefing in qualitative research: Emerging operational models. Qualitative Inquiry, 4, 280-292.

Strauss, A., \& Corbin, J. (1990). Basics of qualitative research: Grounded theory procedures and techniques. Newbury Park, CA: Sage Publications.
Terre des hommes Italia. (2005). Brothel based and floating sex workers in Bangladesh: Living conditions and socio-economic status. Dhaka: Terre des hommes Italia.

The Daily Star (1998, April 23). The suppression of violence against women and children bill 1998: Some suggestions for change. The Daily Star, 23 April, Dhaka, Bangladesh.

Thomas, A., \& Mohan, G. (2007). Research skills for policy and development: How to find out fast. Milton Keynes: The Open University in association with Sage Publications.

UNICEF. (2005). Child sexual abuse, exploitation and trafficking in Bangladesh. Dhaka: UNICEF Bangladesh.

UNICEF. (2009). Global study on child poverty and disparities: National report Bangladesh. Dhaka: UNICEF Bangladesh.

UNICEF. (2011). Sexual abuse and commercial exploitation of children: Elements for a national strategy and plan of action. Dhaka: UNICEF Bangladesh.

World Conference on Education for All (WCEFA). (1990). World declaration on education for all and framework for action to meet basic learning needs. New York: The Inter-Agency Commission for the World Conference on Education for All.

Received November 16, 2012

Revision Received December 16, 2012 Accepted December 30, 2012 